\title{
Oral Corticosteroid Therapy for Preventing Postherpetic Neuralgia: A Systematic Review and Meta-analysis
}

\author{
Alexander Heatrice II ${ }^{1}$, Mahsa Alavi ${ }^{1}$, Phuu P. Han $^{2}$, Reyes Enciso ${ }^{2, *}$ \\ ${ }^{1}$ Herman Ostrow School of Dentistry, University of Southern California, USA \\ ${ }^{2}$ Division of Dental Public Health and Pediatric Dentistry, Herman Ostrow School of Dentistry, University of Southern California, USA
}

Copyright $\mathrm{O} 2017$ by authors, all rights reserved. Authors agree that this article remains permanently open access under the terms of the Creative Commons Attribution License 4.0 International License

\begin{abstract}
The purpose of this systematic review was to examine the efficacy of oral corticosteroids for prevention of postherpetic neuralgia (PHN). Randomized controlled trials of patients suffering from herpes zoster comparing corticosteroids to control therapy (placebo or carbamazepine) or acyclovir were included. Three electronic databases (MEDLINE via PubMed, Web of Science and The Cochrane Library) were searched. Two authors assessed all eligible studies for risk of bias. Ninety-one references were found. After applying inclusion/exclusion criteria 7 studies were eligible for this systematic review. All 7 studies were at high risk of bias. Corticosteroids, rather than carbamazepine, protected the patients against PHN (Relative Risk [RR] = $0.543,95 \%$ CI 0.087 to $3.376, p=0.512$ ), however the results were not statistically significant. Additionally, a second meta-analysis showed that the use of corticosteroids does not prevent PHN compared to the use of a placebo $(\mathrm{RR}=0.990$, $95 \%$ CI 0.092 to $10.663, \mathrm{p}=0.994)$. Mild and reversible side effects were reported in patients taking only corticosteroids; two serious cardiovascular events were reported in the patients prescribed acyclovir and corticosteroid, though those two events were probably unrelated to the therapy. Individual studies reported quality of life improvements and reduction in the incidence and severity of pain with the addition of prednisone to acyclovir therapy; however the heterogeneity of the outcomes and comparison group prevented from performing meta-analyses on these outcomes. Due to the low number of studies, high risk of bias, heterogeneity of the outcomes and comparison groups, the evidence this systematic review provided was of low quality.
\end{abstract}

Keywords Postherpetic Neuralgia (PHN), Corticosteroids, Placebo, Herpes Zoster, and Randomized Controlled Trials

\section{Introduction}

Varicella zoster, the virus that causes the childhood
Varicella (chickenpox), never leaves the body once it has been introduced. Once chickenpox has resolved, the virus retreats into the dorsal root ganglia where it remains dormant. In most cases, it remains inactive for a lifetime, however, the virus can become active again if the host's immunity is weakened by disease, stress or aging. If the virus is reactivated, it causes a painful cutaneous rash known as shingles or herpes zoster. Early symptoms of shingles include pain, burning, tingling and numbness in the area around the affected nerves several days before the rash appears. These symptoms may be followed by headache, light sensitivity and flulike symptoms (usually without fever) just before or along with the start of a rash that usually lasts three to five weeks $[1,2]$. The rash starts with blistering, followed by crusting over and finally healing [1]. After resolution of the lesions associated with herpes zoster, persistent pain may continue and can profoundly affect a patient's quality of life $[3,4]$. Pain may continue for months or years or a lifetime and it is commonly diagnosed as postherpetic neuralgia (PHN). This chronic pain is the most common complication of herpes zoster and its prevalence increases with age. An estimated $12.5 \%$ of patients with herpes zoster aged 50 years or older developed PHN three months after zoster onset [5].

Postherpetic pain may take several forms including allodynia in which a stimulus such as light touching is perceived as painful, hyperpathia in which severe pain induced by nociceptive stimuli is reported by the patient and dysesthesia where sensations are felt when there are no stimuli present $[6,7]$. Due to PHN complexity, management is difficult. A variety of treatments are offered but their effectiveness in reducing symptoms is ambiguous. Corticosteroids are used as anti-inflammatory therapy for patients suffering with pain and inflammation during acute herpes zoster outbreak for prevention of PHN [6]. Previous studies, aimed at assessing the effectiveness of corticosteroid therapies (prednisone or triamcinolone) in preventing PHN, provide contradictory results $[8,9]$. In their review, Han et al. [10] concluded that oral corticosteroids did not prevent PHN six months after herpes onset. The changes or symptoms that 
occur during PHN are complicated, therefore, the efficacy of a single therapy treatment for controlling PHN is uncertain [11]. Three trials compared an antiviral agent (acyclovir) alone with a combination of oral corticosteroids and acyclovir, however, the effectiveness of these combination therapies was inconclusive [12-14]. Despite the absence of evidence regarding interventions with corticosteroids, these therapies are commonly used in the treatment of herpes zoster. Therefore, a systematic review to examine the effectiveness of oral corticosteroids in preventing and treating PHN is needed. This work addresses the question of whether intervention therapies such as oral corticosteroid therapy can prevent or reduce PHN in patients with herpes zoster.

\section{Materials and Methods}

The following electronic databases were searched on June 7, 2016: MEDLINE via PubMed, the Web of Science and The Cochrane Library. The search strategy was as follows: (Postherpetic neuralgia OR post herpetic neuralgia) AND (Corticosteroid OR Prednisone). PubMed search was limited to English language and Human species. An update of the search on April $24^{\text {th }}, 2017$ did not produce any new relevant studies for inclusion. Studies were selected using the following criteria: 1) limited to randomized controlled trials in the prevention of PHN, 2) participant patients were limited to those with painful herpes zoster in the first week (0-7 days) of vesicles formation before study enrollment, 3) corticosteroids (prednisone, prednisolone or triamcinolone) administered orally with or without acyclovir and 4) trials comparing effectiveness of corticosteroids with control treatment (placebo or carbamazepine) or acyclovir.

Editorials, letters to the editor, commentaries, reviews, case studies, animal studies, cost-effectiveness studies, pharmacokinetic studies and guidelines were omitted. Based on the inclusion criteria, two reviewers (AH, MA) independently screened all abstracts and titles resulting from the electronic search as well as the cross-referencing process, and decided to include or exclude the reference for full-text review. For those references where the inclusion was unclear, the full article was assessed for inclusion/exclusion criteria. Reasons for exclusion were recorded in a table format for further reference.

Two independent reviewers (AH, MA) were responsible for extracting the data from the eligible studies related to participant's demographics, interventions, control therapy and outcomes. The assessment of risk of bias with respect to the Randomized Controlled Trials was initially implemented independently by two authors (MA, AH) in accordance with the method described in the Cochrane Handbook for Systematic Reviews of Interventions [15]. (Table 1) The extraction data table prepared for each study included: primary outcome, in this systematic review was the incidence of PHN, defined as pain lasting more than thirty days after onset of herpes zoster; secondary outcomes, reported by some of the studies included in this systematic review: 1) Pain intensity; the intensity of pain in the acute phase among the treated and control group (absent, slight, moderate or severe). 2) Rate of healing; the last day with new lesions, the first day without new vesicles, the first day with full crusting, the time to $100 \%$ healing of the rash, the times of first cessation of pain and the complete cessation of pain. 3) Quality of life parameters; return to $100 \%$ usual activities, return to uninterrupted sleep, and cessation of analgesic agents during a 6-month period. 4) Adverse events reported in the study; serious adverse events were counted as those events which were life threatening requiring prolonged hospitalization or caused death of the patient.

Studies reporting the number of patients developing PHN during the trial were included in the meta-analysis. Risk ratios with 95\% Confidence Intervals (CI) were reported for each eligible study in the meta-analysis as well as the overall pooled result. Statistical heterogeneity was assessed by means of the Cochran's test [16] and quantified by the $\mathrm{I}^{2}$ statistic [17]. To measure the treatment effects, the estimates of the effect were combined using a random-effects model if statistically significant heterogeneity was found (Cochran's $\mathrm{Q}$ test $\mathrm{p}<.010$ ), otherwise, the fixed-effect model was used. Subgroup analyses are presented for studies comparing corticosteroids versus a placebo group and corticosteroids versus carbamazepine, used as a control therapy in two studies. All statistical analyses were performed with Comprehensive Meta-analysis software version 2 (Biostat, Englewood, NJ, USA). Quality of evidence assessment was conducted using the software GRADE profiler $^{\mathcal{O}}[15]$.

Table 1. Summary of risk of bias for eligible studies.

\begin{tabular}{|c|c|c|c|c|c|c|c|}
\hline Study & $\begin{array}{c}\text { Random } \\
\text { Seq. } \\
\text { Generation }\end{array}$ & $\begin{array}{l}\text { Allocation } \\
\text { Concealment }\end{array}$ & Blinding & $\begin{array}{c}\text { Incomplete } \\
\text { Outcome } \\
\text { Data }\end{array}$ & $\begin{array}{l}\text { Selective } \\
\text { Reporting }\end{array}$ & $\begin{array}{l}\text { Other } \\
\text { potential } \\
\text { bias }\end{array}$ & $\begin{array}{l}\text { Overall } \\
\text { Bias }\end{array}$ \\
\hline Benoldi et al.[18] (1991) & $? ? ?$ & +++ & +++ & ---- & ---- & +++ & +++ \\
\hline Clemmensen and Andersen, [19] (1984) & $? ? ?$ & $? ? ?$ & $? ? ?$ & ----- & ---- & +++ & +++ \\
\hline Eaglstein et al. [8] (1970) & $? ? ?$ & ---- & ---- & ----- & ---- & +++ & +++ \\
\hline Esmann et al. [13] (1987) & $? ? ?$ & $? ? ?$ & $? ? ?$ & ----- & ----- & +++ & +++ \\
\hline Whitley et al.[14] (1996) & ---- & ---- & ---- & ----- & ---- & +++ & +++ \\
\hline Wood et al. [12] (1994) & --- & $? ? ?$ & $? ? ?$ & ----- & --- & +++ & +++ \\
\hline
\end{tabular}

KEY: +++ High risk of bias; ---- Low risk of bias; ??? Unclear risk of bias 


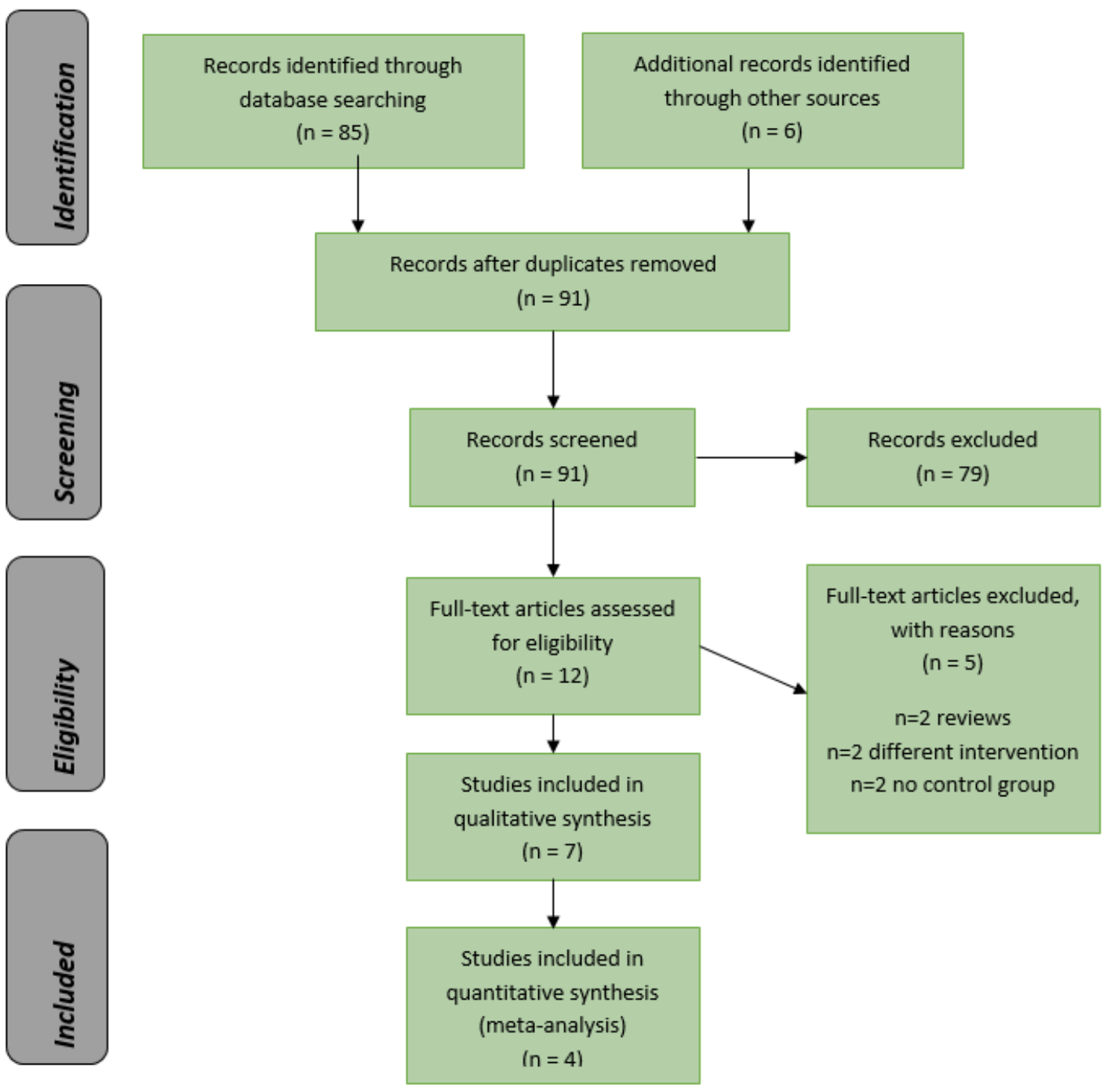

Figure 1. PRISMA Flow Diagram

\section{Results}

The initial search strategy yielded 85 unduplicated references and 6 additional references were found during cross-referencing citations of the reviews and included papers, which based on the abstracts they were reduced to 12 relevant manuscripts. Main reasons for exclusion were: abstract of some conference proceedings without details for inclusion in this review $(n=1)$, case report/case series $(n=3)$, different conditions $(\mathrm{n}=47)$, different interventions $(\mathrm{n}=9)$, different outcome reported than incidence or severity of PHN ( $\mathrm{n}=1)$, not an RCT $(\mathrm{n}=1)$, no placebo group $(\mathrm{n}=1)$, opinion/editorial $(n=3)$ or a review $(n=13)$. All twelve manuscripts identified were further analyzed for inclusion independently by two review authors and five more studies were rejected after full-text review. Figure. 1 shows the PRISMA flow diagram.

The seven included studies were RCTs, $67 \%$ of the studies were double-blinded, while the remaining $[9,18]$ had no indication of whether or not they were double blinded (Table 2). The sample size ranged from 35 [8] to 349 [12] participants. All participants were diagnosed with early signs of herpes zoster, all were adults ranging in age from 21 to 91 years old. The gender of the participants was provided in all of the studies except for one [14] in which the study outlined that slightly more than $50 \%$ of the participants were women. The two corticosteroids under study were prednisone and triamcinolone; three studies compared corticosteroid to a placebo [8, 13, 19], two compared corticosteroid to carbamazepine $[9,18]$ and two compared acyclovir with or without a concomitant corticosteroid $[12,14]$ for the treatment of herpes zoster and prevention of PHN. Drug dosage for each intervention is indicated in Table 5.

The risk of bias of all 7 studies are shown in Table 1 and summarized in Figure 2. Overall, the risk of bias for all studies was high. 
Table 2. Summary of eligible studies

\begin{tabular}{|c|c|c|c|c|c|c|}
\hline Reference & $\begin{array}{l}\text { Year, } \\
\text { Country, } \\
\text { Sample } \\
\text { Size } \\
\end{array}$ & $\begin{array}{c}\text { Participants } \\
\text { Gender (F/M) } \\
\text { Mean age (years) }\end{array}$ & Follow-up & $\begin{array}{l}\text { Interventions and sample } \\
\text { size }\end{array}$ & Inclusions & Bias \\
\hline $\begin{array}{l}\text { Benoldi et } \\
\text { al.[18] } \\
(1991)\end{array}$ & $\begin{array}{l}1991 \\
\text { USA, } \\
\mathrm{N}=36\end{array}$ & $\begin{array}{c}20 \mathrm{~F} / 16 \mathrm{M} \\
\text { Mean age: } 65.8\end{array}$ & 1 year & $\begin{array}{c}\text { Prednisone }(\mathrm{n}=9) \\
\text { Acyclovir }(\mathrm{n}=9) \\
\text { Radiotherapy }(\mathrm{n}=9) \\
\text { Carbamazepine }(\mathrm{n}=9)\end{array}$ & $\begin{array}{c}\text { Over } 50 \text { years of age, } \\
\text { with early (less than } 72 \\
\text { hours), severe, } \\
\text { painful HZ }\end{array}$ & High \\
\hline $\begin{array}{l}\text { Clemmensen } \\
\text { and } \\
\text { Andersen, } \\
{[19]} \\
(1984)\end{array}$ & $\begin{array}{c}1984, \\
\text { Denmark } \\
\mathrm{N}=55\end{array}$ & $\begin{array}{l}\text { 1)Prednisone } 6 \mathrm{~F} / 13 \mathrm{M} \\
\text { Mean age: } 56 \\
\text { 2) ACTH } 7 \mathrm{~F} / 10 \mathrm{M} \\
\text { Mean age: } 55 \\
\text { 3) Placebo } 9 \mathrm{~F} / 10 \mathrm{M} \\
\text { Mean age: } 56\end{array}$ & 6 weeks & $\begin{array}{c}\text { Prednisone }(n=19) \\
\text { ACTH }(n=17) \\
\text { Placebo }(n=19)\end{array}$ & $\begin{array}{l}\text { Early symptoms of } \mathrm{HZ} \\
\text { (3.8- } 4.1 \text { days after the } \\
\text { onset of symptoms.) }\end{array}$ & High \\
\hline $\begin{array}{l}\text { Eaglstein et } \\
\text { al. [8] (1970) }\end{array}$ & $\begin{array}{l}1970 \\
\text { USA, } \\
\mathrm{N}=34\end{array}$ & Age: $21-91$ years old & 8 weeks & $\begin{array}{c}\text { Triamcinolone }(\mathrm{n}=15) \\
\text { Placebo (Lactose tablet) } \\
(\mathrm{n}=19)\end{array}$ & $\begin{array}{l}\text { Adults with maximum } 5 \\
\text { days after the onset of } \\
\text { skin lesions. }\end{array}$ & High \\
\hline $\begin{array}{l}\text { Esmann et al. } \\
{[13](1987)}\end{array}$ & $\begin{array}{c}1987 \\
\text { Denmark } \\
\mathrm{N}=78\end{array}$ & $\begin{array}{c}\text { 1)Acyclovir+prednisolone } \\
\text { 24F/17M } \\
\text { Mean Age: } 72.8 \\
\text { 2) Acyclovir+ placebo } \\
\text { 29F/8M } \\
\text { Mean Age: } 71.4\end{array}$ & 26 weeks & $\begin{array}{l}\text { Acyclovir+prednisolone } \\
(\mathrm{n}=41) \\
\text { Acyclovir+placebo } \\
(\mathrm{n}=37)\end{array}$ & $\begin{array}{l}60 \text { years old patients, the } \\
\text { rash and /or the pain had } \\
\text { been present for less } \\
\text { than } 96 \mathrm{~h} \text { before } \\
\text { admission. }\end{array}$ & High \\
\hline $\begin{array}{l}\text { Keczkes and } \\
\text { Basheer [9] } \\
\quad(1980)\end{array}$ & $\begin{array}{c}1980 \\
\text { England, } \\
\mathrm{N}=40\end{array}$ & $\begin{array}{c}\text { 1) Prednisolone } \\
\text { 6F/14M } \\
\text { Mean Age: } 66.4 \\
\text { 2) Carbamazepine } \\
\text { 6F/14M } \\
\text { Mean Age: } 68.5\end{array}$ & Over 1 year & $\begin{array}{l}\text { Prednisolone }(n=20) \\
\text { Carbamazepine }(n=20)\end{array}$ & $\begin{array}{c}\text { Patients over } \\
50 \text { years of age } \\
\text { with early, severe } \\
\text { painful herpes zoster }\end{array}$ & High \\
\hline $\begin{array}{l}\text { Whitley et } \\
\text { al.[14] } \\
\text { (1996) }\end{array}$ & $\begin{array}{c}1996 \\
\text { USA } \\
\mathrm{N}=201\end{array}$ & $\begin{array}{l}\text { 1) Acyclovir+prednisone } \\
\text { 27F/24M } \\
\text { Age: } 63 \\
\text { 2) Acyclovir } 27 \mathrm{~F} / 21 \mathrm{M} \\
\text { Age: } 62 \\
\text { 3) Prednisone } 24 \mathrm{~F} / 26 \mathrm{M} \\
\text { Age: } 60 \\
\text { 4) Placebo } 27 \mathrm{~F} / 25 \mathrm{M} \\
\text { Age: } 61\end{array}$ & 6 months & $\begin{array}{l}\text { Acyclovir }+ \text { prednisone } \\
\qquad(\mathrm{n}=51) \\
\text { Acyclovir }(\mathrm{n}=48) \\
\text { Prednisone }(\mathrm{n}=50) \\
\text { Placebo group }(\mathrm{n}=52)\end{array}$ & $\begin{array}{l}\text { Patients older than } 50 \\
\text { years of age who had } \\
\text { localized herpes zoster } \\
\text { that developed less than } \\
72 \text { hours before study } \\
\text { enrollment. }\end{array}$ & High \\
\hline $\begin{array}{l}\text { Wood et al. } \\
{[12]} \\
(1994)\end{array}$ & $\begin{array}{l}1994, \\
\text { England } \\
\mathrm{N}=400\end{array}$ & $\begin{array}{l}\text { 1) 7-day acyclovir }+ \\
\text { 21-days steroid } 62 \mathrm{~F} / 37 \mathrm{M} \\
\text { Mean Age: } 59 \\
\text { 2) 7-day acyclovir } 62 \mathrm{~F} / 39 \mathrm{M} \\
\text { Mean age: } 58 \\
\text { 3) 21-day acyclovir }+21 \text { - days } \\
\text { steroid } 60 \mathrm{~F} / 39 \mathrm{M} \\
\text { Mean Age: } 60 \\
\text { 4) 21-day acyclovir } 63 \mathrm{~F} / 38 \mathrm{M} \\
\text { Mean Age: } 59\end{array}$ & 6 months & $\begin{array}{l}\text { 7-day acyclovir with } \\
\text { 21-day Prednisolone } \\
(\mathrm{n}=99) \\
\text { 7-day acyclovir }(\mathrm{n}=101) \\
\text { 21-day acyclovir with } \\
\text { 21-day Prednisolone } \\
(\mathrm{n}=99) \\
\text { 21-day Acyclovir } \\
(\mathrm{n}=101)\end{array}$ & $\begin{array}{l}\text { Adults }>18 \text { years of age } \\
\text { without immune } \\
\text { dysfunction due to } \\
\text { cancer or } \\
\text { immunosuppressive } \\
\text { therapy, who presented } \\
\text { with a clinical diagnosis } \\
\text { of herpes zoster as } \\
\text { and had a rash for } 72 \\
\text { hours or less and at least } \\
\text { moderate pain. }\end{array}$ & High \\
\hline
\end{tabular}

$\mathrm{ACTH}=$ Adrenocorticotropic hormone. 


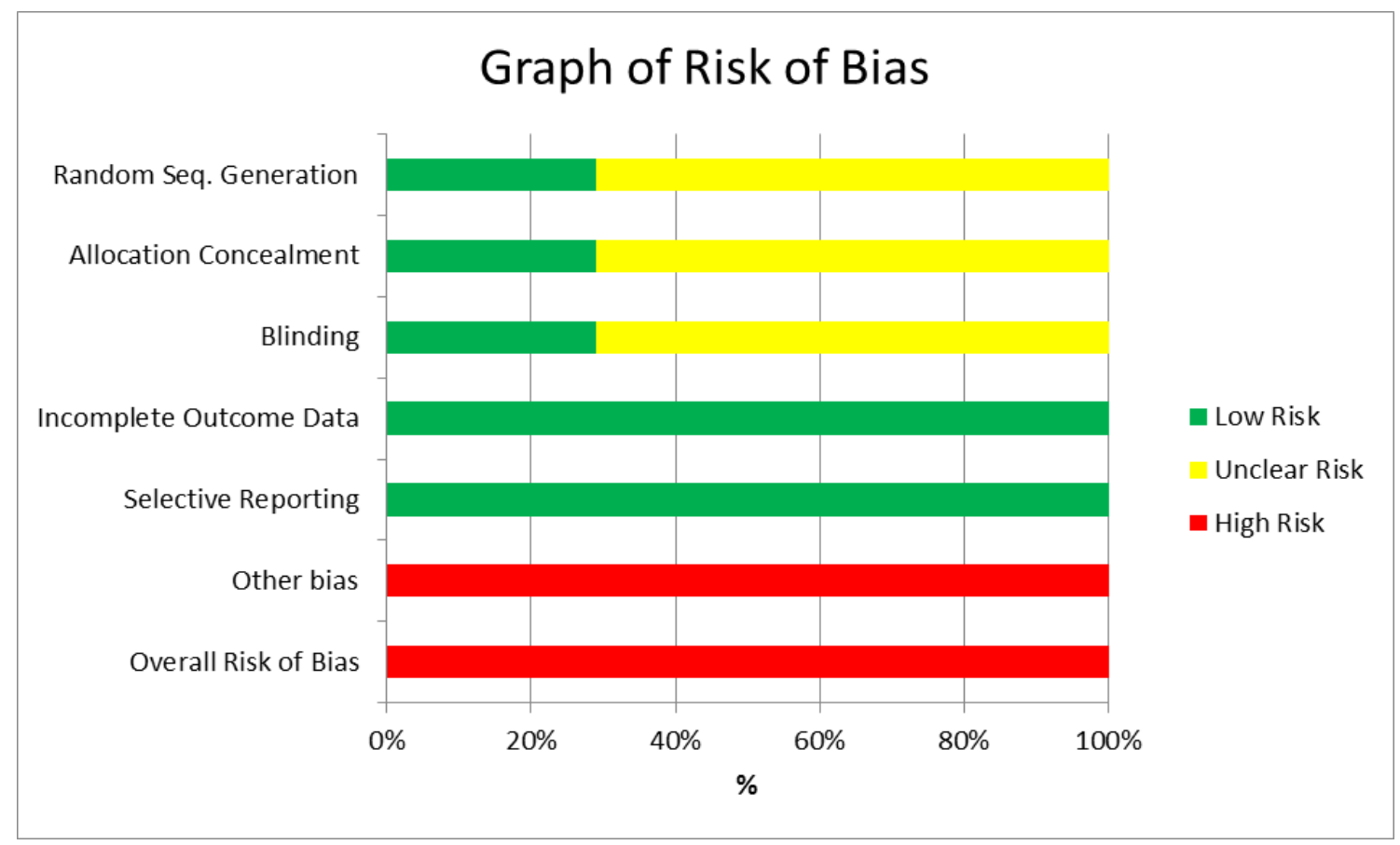

Figure 2. Graph of risk of bias for eligible studies.

Table 3. Summary of outcomes for incidence of PHN in RCTs comparing corticosteroids to carbamazepine

\begin{tabular}{|c|c|c|c|c|c|}
\hline$\underline{\text { Study }}$ & Interventions & Outcome & $\begin{array}{l}\text { Incidence of PHN } \\
\text { in Corticosteroid } \\
\text { group (\%) }\end{array}$ & $\begin{array}{l}\text { Incidence of PHN in } \\
\text { Control group } \\
\text { (\%) }\end{array}$ & $\frac{R R}{195 \% C I I}$ \\
\hline $\begin{array}{l}\text { Benoldi et al. } \\
{[18](1996)}\end{array}$ & $\begin{array}{l}\text { Prednisone } 35 \mathrm{mg} / \text { day for } \\
10 \text { days with gradual } \\
\text { reduction to zero over the } \\
\text { next } 3 \text { weeks }(\mathrm{n}=9) \\
\text { Carbamazepine } 100 \mathrm{mg} \\
\text { four times a day for } 4 \\
\text { weeks }(\mathrm{n}=9)\end{array}$ & $\begin{array}{l}\text { Incidence of PHN } \\
\text { measured at } 2 \\
\text { months }\end{array}$ & $\begin{array}{l}3 / 9 \\
(33 \%)\end{array}$ & $\begin{array}{l}2 / 9 \\
(22 \%)\end{array}$ & $\begin{array}{l}\mathrm{RR}=1.5 \\
{[0.324,6.942]} \\
\mathrm{P}=0.604\end{array}$ \\
\hline $\begin{array}{l}\text { Keczkes and } \\
\text { Basheer[9] } \\
(1980)\end{array}$ & $\begin{array}{l}\text { Prednisolone } 40 \mathrm{mg} \text { daily } \\
\text { for } 10 \text { days with gradual } \\
\text { reduction over a period of } \\
3 \text { weeks }(\mathrm{n}=20) \\
\text { Carbamazepine } 100 \mathrm{mg} \\
\text { four times daily for } 4 \\
\text { weeks }(\mathrm{n}=20)\end{array}$ & $\begin{array}{l}\text { Incidence of PHN } \\
\text { measured at } 2 \\
\text { months }\end{array}$ & $\begin{array}{l}3 / 20 \\
(15 \%)\end{array}$ & $\begin{array}{l}13 / 20 \\
(65 \%)\end{array}$ & $\begin{array}{l}\mathrm{RR}=0.231 \\
{[0.077,0.688]} \\
\mathbf{P}=\mathbf{0 . 0 0 8}\end{array}$ \\
\hline
\end{tabular}

\section{Incidence of PHN: treated versus controls}

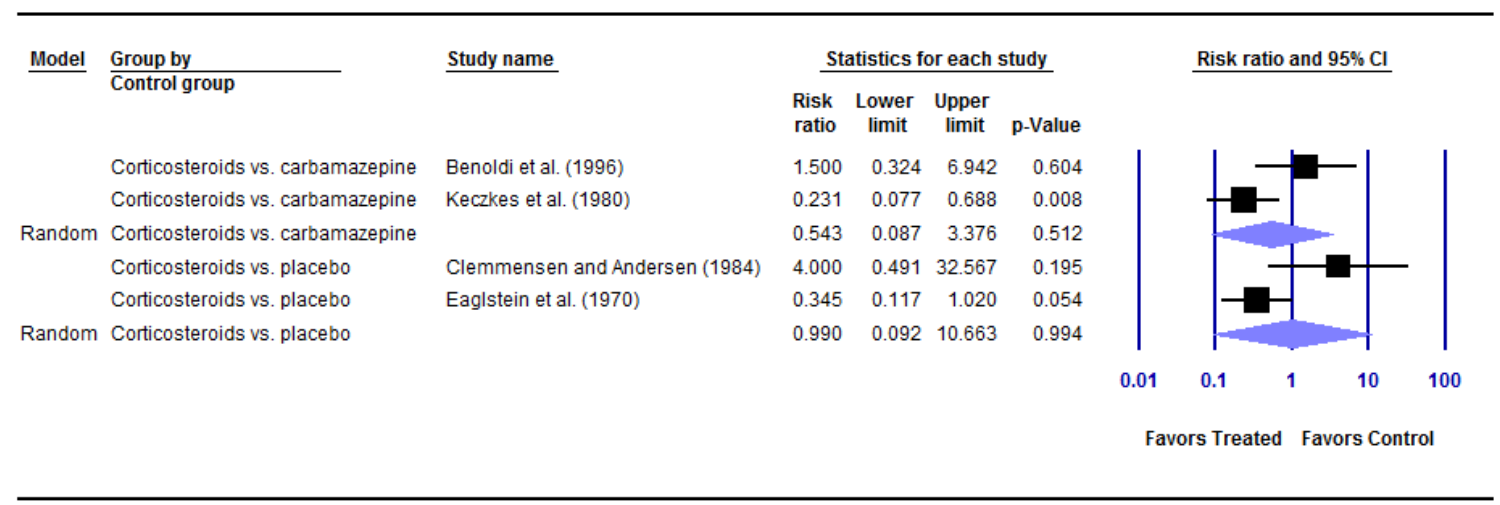

Random effects model

Figure 3. Subgroup analysis by control group: Corticosteroids versus carbamazepine or placebo. 


\subsection{Effects of Interventions}

Of the seven studies included in the qualitative synthesis, five $[8,9,13,18,19]$ reported incidence of PHN and two [12, 14] did not and could not be included in the meta-analysis. Two studies compared corticosteroids versus placebo $[8,19]$, two compared corticosteroids versus carbamazepine $[9,18]$, and three studies [12-14] compared corticosteroids + acyclovir to acyclovir alone. Only studies comparing similar interventions were pooled together in a meta-analysis. Subgroup analyses comparing corticosteroids to placebo or carbamazepine are presented in Figure 3.

\subsubsection{Corticosteroids vs. Carbamazepine.}

Two studies reported the incidence of PHN in patients treated with corticosteroids versus carbamazepine $[9,18]$ (Table 3). In Benoldi et al [18], the patients started at $35 \mathrm{mg}$ of prednisone per day for 10 days with gradual reduction to zero over the next 3 weeks, compared to $40 \mathrm{mg}$ prednisolone in Keczkes and Basheer [9]. Sample size was 9 in Benoldi et al [18] compared to 20 participants in each group in Keczkes and Basheer [9]. Both studies compared to carbamazepine $100 \mathrm{mg}$ four times a day for 4 weeks. There was moderate heterogeneity among the two studies [9], [18] comparing corticosteroids with carbamazepine (Q-test $\mathrm{p}=.051 ; \mathrm{I}^{2}=73 \%$ ). Using the random-effects model, the pooled results showed that patients treated with corticosteroids were less likely to develop PHN than patients taking carbamazepine ( $R R=0.543,95 \%$ CI 0.087 to 3.376 , $\mathrm{p}=0.512$ ) but this difference was not statistically significant (Figure 3).

In Benoldi et al [18], the intensity of pain was measured in the acute phase and it decreased in the prednisone group from severe to slight or absent $(p<0.5)$ in six patients. In the control group only one patient had pain reduction from severe to moderate $(\mathrm{p}<0.5)$. In Keczkes and Basheer [9] pain relief time was measured after PHN: no patient had pain exceeding 6 months in the prednisolone group while four patients had pain lasting 1 year or longer in the carbamazepine group. They also measured the skin healing time, which was significantly shorter in the prednisolone group (3.65 weeks) compared to the carbamazepine group (5.25 weeks). In conclusion, though PHN could not be prevented, the severity or duration of PHN was reduced more in the prednisolone group than in the carbamazepine group.

\subsubsection{Corticosteroids vs. Placebo}

Two studies compared corticosteroids versus placebo and were included in a meta-analysis $[8,19]$ (Table 4; Figure 3). Two different corticosteroids were used in the studies: in the first study [19], patients received $45 \mathrm{mg}$ of prednisone daily during the first week, $30 \mathrm{mg}$ daily in the second week and tapering to zero during the third week, compared to $48 \mathrm{mg}$ / day of triamcinolone for 7 days, $24 \mathrm{mg} /$ day for 7 days and $16 \mathrm{mg} /$ day for 7 days (a total of 3 weeks) in the second study ${ }^{8}$. The first study measured the incidence of PHN at 6 weeks [19] and the second one at 8 weeks. Sample sizes were similar in both studies. There was statistically significant heterogeneity among the two studies $[8,19]$ comparing corticosteroids with placebo (Q-test $\mathrm{p}=.042 ; \mathrm{I}^{2}=76 \%$ ) (Table 4). Using the random-effects model, the pooled results showed that corticosteroids did not significantly prevent PHN compared to placebo $(\mathrm{RR}=0.990,95 \% \mathrm{CI}$ 0.092 to $10.663, \mathrm{p}=0.994$ ) (Figure 3).

Whitley et al [14] showed that healing was not accelerated in patients receiving prednisone + acyclovir placebo as compared with patients receiving two placebos. However, in terms of quality of life, prednisone recipients were 1.74 times $(p<.05)$ more likely to return to $100 \%$ usual activity than were patients who did not receive prednisone [14], in conclusion, though healing was not improved in the corticosteroids group, quality of life was improved. Clemmensen and Andersen [19] reported no significant differences between the prednisone group and the placebo group in degree of pain, number of days until no further vesicles appeared or until all disappeared, or until crusts appeared. Eaglstein et al [8] did not report significant differences in skin healing time between corticosteroids and placebo groups [8]. Some patients in this study received analgesics of morphine class if needed [19]. That could have potentially biased the results if patients in the placebo group had less pain due to the co-intervention.

Table 4. Summary of outcomes for incidence of PHN in RCTs comparing corticosteroids to placebo

\begin{tabular}{|c|c|c|c|c|c|}
\hline Study & Interventions & Outcome & $\begin{array}{l}\text { Incidence of PHN in } \\
\text { Corticosteroid group } \\
(\%)\end{array}$ & $\begin{array}{c}\text { Incidence of PHN in } \\
\text { Placebo group } \\
(\%)\end{array}$ & $\begin{array}{c}\text { RR } \\
{[95 \% \mathrm{CI}]} \\
\text { p-value }\end{array}$ \\
\hline $\begin{array}{c}\text { Clemmensen and } \\
\text { Andersen, [19] } \\
\text { (1984) }\end{array}$ & $\begin{array}{l}\text { Prednisone } 45 \mathrm{mg} \text { daily during } \\
\text { the } 1 \text { st week, } 30 \mathrm{mg} \text { daily } \\
\text { during the } 2 \mathrm{nd} \text { week, and } 15 \\
\text { mg daily tapered to zero during } \\
\text { the } 3 \text { rd week (n=19) } \\
\text { Placebo }(\mathrm{n}=19)\end{array}$ & $\begin{array}{l}\text { Incidence of PHN } \\
\text { at } 6 \text { weeks }\end{array}$ & $\begin{array}{c}4 / 19 \\
(21 \%)\end{array}$ & $\begin{array}{c}1 / 19 \\
(5.3 \%)\end{array}$ & $\begin{array}{c}\mathrm{RR}=4.0 \\
{[0.491,32.6]} \\
\mathrm{p}=0.195\end{array}$ \\
\hline $\begin{array}{l}\text { Eaglstein et al. [8] } \\
\qquad(1970)\end{array}$ & $\begin{array}{c}\text { Triamcinolone } 48 \mathrm{mg} / \text { day for } \\
\text { seven days, } 24 \mathrm{mg} / \text { day for } \\
\text { seven days, and } 16 \mathrm{mg} / \text { day for } \\
\text { seven days. }(\mathrm{n}=15) \\
\text { Placebo }(\mathrm{n}=19)\end{array}$ & $\begin{array}{l}\text { Incidence of PHN } \\
\text { at } 8 \text { weeks }\end{array}$ & $\begin{array}{l}3 / 15 \\
(20 \%)\end{array}$ & $\begin{array}{l}11 / 19 \\
(73 \%)\end{array}$ & $\begin{array}{c}\mathrm{RR}=0.345 \\
{[0.117,1.020]} \\
\mathrm{p}=0.054\end{array}$ \\
\hline
\end{tabular}




\subsubsection{Corticosteroid vs. Acyclovir}

One study provided incidence data of PHN in a group treated with corticosteroid compared to a group treated with acyclovir at two months $(33 \%$ in corticosteroids group versus $22 \%$ in acyclovir group; $p>.05$ ) [18]. At six months after the acute phase, only patients in the acyclovir group did not develop neuralgia however, one in nine patients in the

prednisone group, one in nine patients in the radiotherapy group and one in nine in the carbamazepine group developed PHN. The other study comparing corticosteroids versus acyclovir [14] did not report the incidence of PHN and could not be included in the meta-analysis. The authors concluded that the resolution of PHN was not significantly accelerated in any active-treatment group (acyclovir or prednisone or acyclovir with prednisone) compared with the placebo group.

Benoldi et al. [18] measured the intensity of pain in the acute phase and reported pre- and post-treatment results; in the prednisone group, six patients had their pain reduced from severe to slight or absent $(p<0.5)$ while in the acyclovir group, five patients had their pain decreased from severe to slight or absent $(\mathrm{P}<0.1)$. In a second study [14], patients who received prednisone, regardless of whether they also received acyclovir, were 2.28 times more likely to have resolution of acute pain during the first months after disease onset than were patients who did not receive prednisone. Also, prednisone recipients were 1.74 times more likely to return to $100 \%$ usual activity than were patients who did not receive prednisone while acyclovir recipients were 1.90 times more likely to return to $100 \%$ usual activity than were patients who did not receive acyclovir [14].

\subsubsection{Acyclovir + Corticosteroids vs. Acyclovir Alone}

Three studies [12-14] compared the efficacy of acyclovir + corticosteroids to acyclovir alone, however no PHN incidence was reported by treatment group and a meta-analysis could not be conducted.
Whitley et al. [14] reported no statistically significant difference $(\mathrm{p}=.10)$ in incidence of PHN between acyclovir + prednisone compared to patients taking acyclovir alone. However, patients receiving acyclovir + prednisone had statistically significant improved quality of life; accelerated time to cessation of acute neuritis $(\mathrm{RR}=3.02 ; \mathrm{p}<.05)$, accelerated time to return to uninterrupted sleep $(R R=2.12$, $\mathrm{p}<.05)$, time to return to usual daily activity $(\mathrm{RR}=3.22, \mathrm{p}<.05)$ and time to cessation of analgesic therapy $(R R=3.15 ; p<.05)$. Therefore, they concluded that in relatively healthy persons older than 50 years of age who have localized herpes zoster, acyclovir + prednisone therapy can improve quality of life [14]. Wood et al. [12] reported no additional reduction of the frequency of PHN with neither steroid or acyclovir for 21 days treatment compared to 7-days. The authors suggested that the addition of prednisolone to acyclovir may confer additional benefit in the healing of rash and in the incidence and severity of pain during the first few weeks of illness but that it has no appreciable influence on the incidence or severity of PHN. In conclusion, acyclovir + corticosteroids may reduce the severity of pain and improve quality of life compared to corticosteroids alone, however no evidence was available in support of the prevention of PHN [12]

\subsection{Side Effects Reported in Included Articles}

As reported in Table 5, side effects were mostly mild in nature in the corticosteroids only group (increasing blood sugar, cutaneous dissemination). Only two studies $[13,14]$ reported side effects which were serious in nature. In Esmann et al [13] one patient in the acyclovir + prednisolone group had cardiac insufficiency and in Whitley et al [14] one patient, again from the acyclovir + prednisone group, died of myocardial infarction at day 26. It is unknown whether these two incidents were related in any way to pharmaceuticals or procedures used in the studies. In one study [12], $21 \%$ of the patients in the acyclovir + prednisolone group had side effects compared to $12 \%$ in the acyclovir only group.

Table 5. Dosage, side effects and co-interventions reported in included papers.

\begin{tabular}{|c|c|c|c|}
\hline Study & Interventions and Dosage & $\begin{array}{l}\text { Co-interventions } \\
\text { (additional medications taken by the patients) }\end{array}$ & $\begin{array}{l}\text { Side effects } \\
\text { by Group }\end{array}$ \\
\hline $\begin{array}{l}\text { Benoldi et al. } \\
\text { [18] (1991) }\end{array}$ & $\begin{array}{l}\text { Prednisone } 35 \mathrm{mg} / \text { day } x 10 \text { days } \\
\text { with gradual reduction to } 0 \\
\text { over next } 3 \text { weeks }(\mathrm{n}=9) \\
\text { Acyclovir } 800 \mathrm{mg} 5 \mathrm{xday} \text { for } 7 \\
\quad \text { days }(\mathrm{n}=9) \\
\text { Radiotherapy } 150 \text { rad twice a } \\
\text { week for } 2 \text { weeks }(\mathrm{n}=9) \\
\text { Carbamazepine } 100 \mathrm{mg} 4 \text { xday } \\
\text { for } 4 \text { weeks }(\mathrm{n}=9)\end{array}$ & $\begin{array}{c}\text { Topical treatment: } \\
\text { Meclocycline ointment } \\
\text { No analgesics were allowed during the acute phase of } \\
\text { illness. }\end{array}$ & $\begin{array}{l}\text { No side effects were observed in } \\
\text { any group }\end{array}$ \\
\hline $\begin{array}{l}\text { Clemmensen } \\
\text { and } \\
\text { Andersen, }[1 \\
9](1984)\end{array}$ & $\begin{array}{l}\text { Prednisone } 45 \mathrm{mg} / \text { daily } \times 1^{\text {st }} \\
\text { week, } 30 \mathrm{mg} / \text { daily } \times 2^{\text {nd }} \text { week, } \\
15 \mathrm{mg} / \text { daily } \times 3^{\text {rd }} \text { week tapered } \\
\text { to zero }(\mathrm{n}=19) \\
\text { ACTH } 1 \mathrm{mg} \text { IM } 3 \text { times/week to } \\
\text { total } 7 \text { times }(\mathrm{n}=17) \\
\text { Placebo }(\mathrm{n}=19)\end{array}$ & $\begin{array}{c}\text { Topical treatment: } \\
\text { Carbowax } 1500 \bigodot \text { once daily } \\
\text { Analgesics were allowed: } \\
\text { Acetylsalicylic acid } 500 \mathrm{mg} \\
\text { Codeine phosphate } 10 \mathrm{mg} \\
\text { Maximum daily dose of } 8 \text { tablets } \\
\text { Analgesics (morphine class) allowed on an emergency } \\
\text { basis. }\end{array}$ & $\begin{array}{l}\text { In prednisone group: (mild and } \\
\text { reversible) } \\
\text { Increasing blood sugar } \\
\text { In } A C T H \text { group: } \\
\text { 1. Uncomfortable dizziness } \\
\text { 2. Moderate periorbital edema }\end{array}$ \\
\hline
\end{tabular}




\begin{tabular}{|c|c|c|c|}
\hline $\begin{array}{l}\text { Eaglstein et } \\
\text { al.[8] (1970) }\end{array}$ & $\begin{array}{c}\text { Triamcinolone } 8 \mathrm{mg} / 2 \text { capsules } \\
3 \mathrm{x} \text { day } \mathrm{x} 1 \text { week, } 1 \text { capsules } 3 \mathrm{x} \\
\text { day } \mathrm{x} 1 \text { week, } 1 \text { capsules } 2 \mathrm{x} \\
\text { day } \mathrm{x} 1 \text { week }(\mathrm{n}=15) \\
\text { Placebo (lactose) }(\mathrm{n}=19)\end{array}$ & $\begin{array}{l}\text { Analgesics were allowed: } \\
\text { Codeine } 64 \mathrm{mg} \text {. } \\
\text { Tap water soaks to the skin lesions. }\end{array}$ & No side effects were reported \\
\hline $\begin{array}{l}\text { Esmann et } \\
\text { al.[13] } \\
(1987)\end{array}$ & $\begin{array}{l}\text { Acyclovir } 800 \mathrm{mg} / 5 \mathrm{x} \text { day } \mathrm{x} 7 \\
\text { days }+ \text { Prednisolone } 40 \mathrm{mg} \\
\text { daily for } 7 \text { days, } 30 \mathrm{mg} \text { for } 4 \\
\text { days, } 20 \mathrm{mg} \text { for } 3 \text { days, } 10 \mathrm{mg} \\
\text { for } 4 \text { days, and finally } 5 \mathrm{mg} \text { for } \\
3 \text { days. } \quad(\mathrm{n}=41) \\
\text { Acyclovir + placebo } 21 \text { Days } \\
(\mathrm{n}=37)\end{array}$ & $\begin{array}{l}\text { Topical treatment: carbowax containing } 0.2 \% \\
\text { chlorhexidine and } 10 \% \text { lignocaine for skin lesions and } 3 \% \\
\text { acyclovir ointment for eye lesions } \\
5 \text { times daily } \\
\text { Analgesics were allowed: } \\
\text { Authors didn't mention the name or the route of } \\
\text { administration. }\end{array}$ & $\begin{array}{l}\text { In Acyclovir+Prednisolone } \\
\text { group: } \\
1 \text { patient had acute cardiac } \\
\text { insufficiency (this patient was } \\
\text { withdrawn during the first } 1-2 \\
\text { weeks from the study start.) }\end{array}$ \\
\hline $\begin{array}{l}\text { Keczkes and } \\
\text { Basheer [9] } \\
\quad(1980)\end{array}$ & $\begin{array}{l}\text { Prednisolone } 40 \mathrm{mg} / \text { day } \mathrm{x} \\
\text { 10days, during } 3 \text { weeks to zero } \\
\qquad(\mathrm{n}=20) \\
\text { Carbamazepine } 100 \mathrm{mg} / 4 \mathrm{x} \text { day } \\
\text { for } 4 \text { weeks }(\mathrm{n}=20)\end{array}$ & $\begin{array}{c}\text { Topical treatment: } \\
\text { Neomycin sulphate } 0.25 \% \\
\text { Gramicidin } 0.025 \% \text { ointment } \\
\text { Talcum powder } \\
\text { No analgesics were allowed during the acute phase of } \\
\text { illness. }\end{array}$ & No side effects were reported \\
\hline $\begin{array}{l}\text { Whitley et } \\
\text { al.[14] } \\
(1996)\end{array}$ & $\begin{array}{c}\text { Acyclovir }+ \text { prednisone }(\mathrm{n}=51) \\
\text { Acyclovir }(\mathrm{n}=48) \\
\text { Prednisone }(\mathrm{n}=50) \\
\text { Placebo group }(\mathrm{n}=52) \\
\text { Acyclovir } 800 \mathrm{mg} 5 \mathrm{x} / \text { day } \times 21 \\
\text { days } \\
\text { Prednisone } 60 \mathrm{mg} / \text { day } \times 1^{\text {st }} \\
\text { week, } 30 \mathrm{mg} / \text { day for days } 8-14, \\
15 \mathrm{mg} / \text { day for days } 15-21\end{array}$ & $\begin{array}{l}\text { Analgesic were used: } \\
\text { Authors didn't mention the name } \\
\text { Nobody used the narcotic analgesics }\end{array}$ & $\begin{array}{c}\text { Side effects in prednisone, } \\
\text { acyclovir and placebo group: } \\
\text { Gastrointestinal symptoms, } \\
\text { especially nausea and vomiting } \\
\text { (21\% of all patients) } \\
\text { Edema, increased leukocyte } \\
\text { counts, altered platelet counts, } \\
\text { bilirubin levels, or hepatic } \\
\text { function test result ( } 2 \% \text { of all } \\
\text { patients) } \\
\text { Serum aspartate glutamyl } \\
\text { transferase levels }>50 \text { U/L ( } 9 \% \\
\text { of all patients) } \\
\text { Hyperglycemia developed in } 7 \\
\text { patients } \\
\text { Side effects in prednisone+ } \\
\text { acyclovir group: } \\
1 \text { patient died of myocardial } \\
\text { infarction on study day } 26 \\
\text { Side effects in prednisone } \\
\text { group: } \\
2 \text { patients developed cutaneous } \\
\text { dissemination } \\
\text { Side effects in acyclovir group: } \\
1 \text { patient developed cutaneous } \\
\text { dissemination } \\
\text { Side effects in placebo group: } \\
1 \text { patient was hospitalized for } \\
\text { bacterial pneumonia }\end{array}$ \\
\hline $\begin{array}{l}\text { Wood et } \\
\text { al.[12] } \\
(1994)\end{array}$ & $\begin{array}{l}\text { 7day acyclovir with 21-day } \\
\text { Prednisolone }(\mathrm{n}=99) \\
\text { 7day acyclovir }(\mathrm{n}=101) \\
\text { 21 day acyclovir with } 21 \text { day } \\
\text { Prednisolone }(\mathrm{n}=99) \\
\text { 21-day acyclovir without } \\
\text { Prednisolone ( } \mathrm{n}=101) \\
\\
\text { Prednisolone } 40 \mathrm{mg} / \text { day for } \\
\text { days } 0-6,30 \mathrm{mg} / \text { day for days } \\
7-10,20 \mathrm{mg} / \text { day for days } 11-14 \text {, } \\
10 \mathrm{mg} / \text { day for days } 15-18 \\
5 \mathrm{mg} / \text { day for days } 19-21 \\
\text { Acyclovir } 800 \mathrm{mg} 5 \mathrm{xday}\end{array}$ & No additional medication was given as co-intervention & $\begin{array}{c}\text { Acyclovir }+ \text { Prednisolone group: } \\
(\mathrm{n}=198) \\
(42 \text { had side effects, } 21 \%) \\
\\
\text { Acyclovir group }+ \text { placebo: } \\
(\mathrm{n}=200 \text { total }) \\
(24 \text { had side effects, } 12 \%)\end{array}$ \\
\hline
\end{tabular}


Table 6. Summary of quality of evidence

\begin{tabular}{|c|c|c|c|c|c|}
\hline \multicolumn{6}{|c|}{ Corticosteroids for preventing PHN } \\
\hline \multirow{2}{*}{ Outcomes } & \multirow{2}{*}{$\begin{array}{c}\text { No of Participants } \\
\text { (studies) } \\
\text { Follow up }\end{array}$} & \multirow{2}{*}{$\begin{array}{l}\text { Quality of the } \\
\text { evidence } \\
\text { (GRADE) }\end{array}$} & \multirow{2}{*}{$\begin{array}{l}\text { Relative effect } \\
\quad(95 \% \mathrm{CI})\end{array}$} & \multicolumn{2}{|c|}{ Anticipated absolute effects } \\
\hline & & & & Risk with Control & \begin{tabular}{|c} 
Risk difference with \\
Corticosteroids \\
$(95 \% \mathrm{CI})$
\end{tabular} \\
\hline $\begin{array}{l}\text { Incidence of PHN } \\
\text { (Corticosteroids versus } \\
\text { carbamazepine) }\end{array}$ & $\begin{array}{c}58 \\
\text { (2 studies) } \\
2 \text { months }\end{array}$ & $\begin{array}{c}\oplus \oplus \Theta \Theta \\
\text { LOW }^{1,2} \\
\text { due to risk of bias, } \\
\text { inconsistency }\end{array}$ & $\begin{array}{c}\text { RR } 0.543 \\
\text { (0.087 to } 3.376)\end{array}$ & 517 per 1000 & $\begin{array}{c}236 \text { fewer per } 1000 \\
\text { (from } 472 \text { fewer to } \\
1000 \text { more) }\end{array}$ \\
\hline $\begin{array}{c}\text { Incidence of PHN } \\
\text { (Corticosteroids versus placebo) }\end{array}$ & $\begin{array}{c}72 \\
\text { (2 studies) } \\
4 \text { weeks }\end{array}$ & $\begin{array}{c}\oplus \oplus \Theta \Theta \\
\text { LOW } \\
\text { due to risk of bias, } \\
\text { inconsistency }\end{array}$ & $\begin{array}{c}\text { RR } 0.990 \\
(0.092 \text { to } 10.663)\end{array}$ & 316 per 1000 & $\begin{array}{c}3 \text { fewer per } 1000 \\
\text { (from } 287 \text { fewer to } \\
1000 \text { more) }\end{array}$ \\
\hline \multicolumn{6}{|c|}{ CI: Confidence interval; RR: Risk ratio; } \\
\hline \multicolumn{6}{|c|}{$\begin{array}{l}\text { GRADE Working Group grades of evidence } \\
\text { High quality: Further research is very unlikely to change our confidence in the estimate of effect. } \\
\text { Moderate quality: Further research is likely to have an important impact on our confidence in the estimate of effect and may change the estimate. } \\
\text { Low quality: Further research is very likely to have an important impact on our confidence in the estimate of effect and is likely to change the estimate. } \\
\text { Very low quality: We are very uncertain about the estimate. }\end{array}$} \\
\hline
\end{tabular}

\subsection{Quality of the Evidence}

The quality of the evidence was low due to high risk of bias and inconsistency of the results (unexplained heterogeneity in subgroup analyses with high I $2>70 \%$ ). (Table 6).

\section{Discussion}

All eligible studies were RCTs; $71 \%$ were double-blinded; the sample sizes ranged between 34 [8] to 349 [12], in all studies except one [12], the participants were immunocompetent adults above 50 years of age, the gender of the participants was reported except for Whitley, et al 10 in which it was only reported that slightly more than $50 \%$ of the participants were women. The participants in all the studies were diagnosed with early signs of herpes zoster. All seven studies used a corticosteroid (with or without acyclovir) in the prevention of post-herpetic neuralgia. Four studies provided data for the primary outcome (incidence of PHN), however due to the heterogeneity in comparison group (placebo, carbamazepine), subgroup analyses for corticosteroids versus placebo and corticosteroids versus carbamazepine are presented. There was moderate heterogeneity between the two studies comparing corticosteroids with carbamazepine; one study shows non-significant difference favoring corticosteroids [9] while the other study shows significant difference favoring carbamazepine [18]. The other two studies showed statistically significant heterogeneity comparing corticosteroids with placebo; one study showed non-significant difference favoring corticosteroids [8], while the other study showed a significant difference-favoring placebo [19].
Three electronic databases were searched (MEDLINE through PubMed, The Web of Science and The Cochrane Library). A limitation of this systematic review is the lack of access to EMBASE database. All included studies and reviews were manually searched for eligible studies. Overall, the results of this systematic review are applicable to both males and females as both genders were present in each of the reviewed studies. The mean age of the participants was between 55 to 73 years old when documented, most of the patients were Caucasian. Pregnant women, breastfeeding mothers and medically compromised patients (tuberculosis, diabetes mellitus, hypertension, cardiovascular diseases, lymphoma and leukemia) were often excluded from the studies. The included studies follow-up ranged from 6 weeks to over a yearlong therefore, some of the studies included in this review did address lingering effects, however, long-term (over one year) effects were not reported.

Only double-blinded RCTs were included in this review. All 7 studies were at high risk of bias. The evidence was low quality due to the high risk of the studies, the small number of studies included in each meta-analysis $(n=2)$ and the inconsistency of the results (unexplained heterogeneity with high I $2>70 \%$ ), heterogeneity of the interventions, comparison interventions (placebo, acyclovir or carbamazepine) and the outcomes (incidence and severity of PHN; incidence, duration and severity of pain), all which made it impossible to compare many studies in one meta-analysis. Reviews published on the topic of corticosteroid efficacy in the prevention of PHN [20-30] agreed with our systematic review results; corticosteroids do not prevent PHN. Also, some reviews [30] were not able to interpret the effect of corticosteroids on PHN due to the poor quality of the evidence. Some reviews found acyclovir 
better than corticosteroids [21, 26], however, others found that a combination therapy of antiviral medication (acyclovir) and corticosteroids may shorten the degree and duration of acute zoster pain [22, 23, 28, 29, 31]. All reviews agreed with this study in recommending further high quality studies to assess the effect of corticosteroids on both short-term pain and long term PHN.

\section{Conclusions}

In conclusion, there is no preventive intervention for PHN at present time. Healthcare providers can only treat PHN with palliative means and reduce the severity of the patients' pain. This systematic review found no conclusive evidence in favor of corticosteroids for the prevention of PHN, although some studies showed that corticosteroids may reduce pain severity and duration of the symptoms [9, 18]. Combination therapy with acyclovir has been shown to reduce the severity of PHN and increase quality of life [12, 14], as well as early intervention could be beneficial [32]. Reported side effects in the corticosteroids group were mild and reversible. Two serious cardiovascular events were reported in the combination therapy group, although the occurrence of these events was not reported to be a result of the therapy $[13,14]$. Future research with multiple centers and homogeneous interventions, comparison groups and outcomes is needed. These trials need to assess long-term results and possible adverse risks in using corticosteroids for patients with herpes zoster [33].

Future studies should also include not only oral administration of the corticosteroid therapy but intravenous and muscular injections as well. Another confounding factor is age. The incidence rates are $10 \%$ in people above forty years and $20 \%$ to $50 \%$ for those above sixty years [ 10 , 33]. However, the condition is rare in adults below the age of thirty. Adults above fifty years of age would likely show different responses compared to younger patients [11]. Adulthood comorbidities such as hypertension and osteoporosis, among others, may compound the results. The study period should not be limited to six months but instead to an extended time frame of not less than one year, so that long-term side effects of the therapy could be assessed. Future studies must consider combination therapy such as acyclovir with various preparations of corticosteroids, as combination therapy has shown promise.

\section{Acknowledgements}

The authors of this review would like to thank Dr. Gayle Macdonald, $\mathrm{PhD}$ and Dr. Margarita Zeichner-David, $\mathrm{PhD}$ at Herman Ostrow School of Dentistry of USC for help with editing and formatting the manuscript.

\section{REFERENCES}

[1] CDC, "Shingles (Herpes Zoster)," Centers for Disease Control and Prevention, 2016. [Online]. Available: http://www.cdc.gov/shingles/hcp/clinical-overview.html.

[2] C. Janniger, J. Eastern, D. Hospenthal, and J. Moon, "Herpes Zoster," Medscape, 2016. [Online]. Available: http://emedicine.medscape.com/article/1132465-overview.

[3] M. Drolet, M. Brisson, K. E. Schmader, M. J. Levin, R. Johnson, M. N. Oxman, D. Patrick, C. Blanchette, and J. A. Mansi, "The impact of herpes zoster and postherpetic neuralgia on health-related quality of life: A prospective study," CMAJ, vol. 182, no. 16, pp. 1731-1736, 2010.

[4] R. W. Johnson, D. Bouhassira, G. Kassianos, A. Leplège, K. E. Schmader, and T. Weinke, "The impact of herpes zoster and post-herpetic neuralgia on quality-of-life.," BMC Med., vol. 8, no. 1, p. 37, 2010.

[5] H. J. Forbes, S. L. Thomas, L. Smeeth, T. Clayton, R. Farmer, K. Bhaskaran, and S. M. Langan, "A systematic review and meta-analysis of risk factors for postherpetic neuralgia.," Pain, vol. 157, pp. 30-54, 2015.

[6] J. Fashner and A. L. Bell, "Herpes zoster and postherpetic neuralgia: Prevention and Management," Am. Fam. Physician, vol. 83, no. 12, pp. 1432-1437, 2011.

[7] K. P. High, "Preventing herpes zoster and postherpetic neuralgia through vaccination.” J. Fam. Pract., vol. 56, no. 10 Suppl A, p. 51A-57A, 2007.

[8] W. H. Eaglstein, R. Katz, and J. A. Brown, "The effects of early corticosteroid therapy on the skin eruption and pain of herpes zoster.” JAMA, vol. 211, no. 10, pp. 1681-3, 1970.

[9] K. Keczkes and A. M. Basheer, "Do corticosteroids prevent post-herpetic neuralgia?” Br. J. Dermatol., vol. 102, no. 5, pp. $551-5,1980$.

[10] Y. Han, J. Zhang, N. Chen, L. He, D. Zhang, M. Zhou, and C. Zhu, "Corticosteroids for preventing postherpetic neuralgia." Cochrane Database Syst. Rev., no. 1, p. CD005582, 2013.

[11] N. Chen, D. Zhang, M. Zhou, and C. Zhu, "Corticosteroids for preventing postherpetic neuralgia." Cochrane Database Syst. Rev., no. 1, p. CD005582, 2010.

[12] M. J. Wood, R. W. Johnson, M. W. McKendrick, J. Taylor, B. K. Mandal, and J. Crooks, "A randomized trial of acyclovir for 7 days or 21 days with and without prednisolone for treatment of acute herpes zoster.," N. Engl. J. Med., vol. 330, no. 13, pp. 896-900, 1994.

[13] V. Esmann, J. Geil, S. Kroon, H. Fogh, N. Peterslund, C. Petersen, J. Ronne-Rasmusen, and L. DANIELSEN, "Prednisolone does not prevent Post-herpetic neuralgia," Lancet, vol. 18, pp. 126-9, 1987.

[14] R. J. Whitley, H. Weiss, J. W. Gnann, S. Tyring, G. J. Mertz, P. G. Pappas, C. J. Schleupner, F. Hayden, J. Wolf, and S. J. Soong, "Acyclovir with and without prednisone for the treatment of herpes zoster. A randomized, placebo-controlled trial. The National Institute of Allergy and Infectious Diseases Collaborative Antiviral Study Group." Ann. Intern. Med., vol. 125, no. 5, pp. 376-83, 1996.

[15] J. Higgins and S. (editors) Green, "Cochrane Handbook for Systematic Reviews of Interventions Version 5.1.0, 2011. 
[16] W. Cochran, "The combination of estimated from different experiments." Biomimetrics, vol. 10, pp. 101-129, 1954.

[17] J. P. T. Higgins and S. G. Thompson, "Quantifying heterogeneity in a meta-analysis.," Stat. Med., vol. 21, no. 11, pp. 1539-58, 2002

[18] D. Benoldi, S. Mirizzi, A. Zucchi, and F. Allegra, "Prevention of post-herpetic neuralgia. Evaluation of treatment with oral prednisone, oral acyclovir, and radiotherapy." Int. J. Dermatol., vol. 30, no. 4, pp. 288-90, 1991.

[19] O. J. Clemmensen and K. E. Andersen, "ACTH versus prednisone and placebo in herpes zoster treatment." Clin. Exp. Dermatol., vol. 9, no. 6, pp. 557-63, 1984.

[20] C. P. Watson, "Postherpetic neuralgia.," Neurol. Clin., vol. 7 , no. 2 , pp. $231-48,1989$.

[21] S. K. Tyring, "Management of herpes zoster and postherpetic neuralgia." J. Am. Acad. Dermatol., vol. 57, no. 6 Suppl, pp. S136-42, 2007.

[22] M. W. Sugeng, G. Yosipovitch, and G. C. Leok, "Post herpetic neuralgia and the dermatologist," Int. J. Dermatol., vol. 40, no. 1, pp. 6-11, 2001.

[23] K. Schmader, "Herpes zoster in the elderly: issues related to geriatrics.” Clin. Infect. Dis., vol. 28, no. 4, pp. 736-9, 1999.

[24] D. R. Robertson and C. F. George, "Treatment of post herpetic neuralgia in the elderly.” Br. Med. Bull., vol. 46, no. 1, pp. 113-23, 1990.

[25] J. B. Reuler and M. K. Chang, "Herpes zoster: epidemiology, clinical features, and management." South. Med. J., vol. 77, no. 9, pp. 1149-56, 1984.
[26] G. Gross, H. Schöfer, S. Wassilew, K. Friese, A. Timm, R. Guthoff, H. W. Pau, J. P. Malin, P. Wutzler, and H. W. Doerr, "Herpes zoster guideline of the German Dermatology Society (DDG).," J. Clin. Virol. vol. 26, no. 3, pp. 277-89-3, 2003.

[27] A. J. M. van Wijck, M. Wallace, N. Mekhail, and M. van Kleef, "Herpes Zoster and Post-Herpetic Neuralgia," Pain Pract., vol. 11, no. 1, pp. 88-97, 2011.

[28] P. J. Christo, G. Hobelmann, and D. N. Maine, "Post-herpetic neuralgia in older adults: evidence-based approaches to clinical management.” Drugs Aging, vol. 24, no. 1, pp. 1-19, 2007.

[29] J. M. Weinberg and N. S. Scheinfeld, "Cutaneous infections in the elderly: diagnosis and management." Dermatol. Ther. vol. 16, no. 3, pp. 195-205, 2003.

[30] T. Lancaster, C. Silagy, and S. Gray, "Primary care management of acute herpes zoster: systematic review of evidence from randomized controlled trials.," Br. J. Gen. Pract., vol. 45, no. 390, pp. 39-45, 1995.

[31] K. Schmader, "Herpes zoster in older adults." Clin. Infect. Dis., vol. 32, no. 10, pp. 1481-6, 2001.

[32] J. S. Massengill and J. L. Kittredge, "Practical considerations in the pharmacological treatment of postherpetic neuralgia for the primary care provider," J. Pain Res., vol. 7, pp. 125-132, 2014.

[33] B. F. Jung, R. W. Johnson, D. R. J. Griffin, and R. H. Dworkin, "Risk factors for postherpetic neuralgia in patients with herpes zoster.," Neurology, vol. 62, pp. 1545-1551, 2004. 